\title{
THE AGGRESSION OF HUMAN ACTIVITIES ON CHALANBEEL A THREAT ON WETLAND ENVIRONMENT: STUDY ON NATORE - RAJSHAHI REGION OF BANGLADESH
}

\author{
M M Rahman ${ }^{1}$, M R Rahman ${ }^{2}$ and M Asaduzzaman ${ }^{3}$
}

\begin{abstract}
The Chalanbeel is the main wetland of Northwestern region of Bangladesh. It is not only the source of water but also one of the main sources of occupation for thousands of people. It supplies fresh water as well as abundant of aquatic resources. This wetland is the large source of native fishes. It plays a vital role to keep the environment of the surrounding vast region balanced. It makes the land fertile, alluvial and alive for whole the year round. It is also a large reservoir of biological diversity of this region. Recently the aggression of man on this great beel increases in such a rate that the overall environment of this wetland fall in a crisis. It is going to loss its tradition and pride of her resources. Specially the aggression of settlement and road construction along the wetland hampered the natural characteristics. Reach it and an investigation was conducted to study the overall condition of the wetland. The observation indicates horror news for both the environment and its inhabitant of the surrounding area. Soils under lower Natore- Rajshahi region of Bangladesh with a view to evaluate the agricultural potentiality, environmental condition and their management options. The studied wetlands were nutritionally very productive. It is believed that the soils of this area became enriched by siltation during flooding. Soil textural condition is very much appropriate for rice production in these basin floodplains. The content of nitrogen and boron is low. Probably, the denitrification process leads to the loss of nitrogen in these soils; other nutrients seem to be in balanced condition for the successful growth of deep water aman and boro rice. High yielding boro rice got preference over broadcast aman and aous as major rice crops in the area. Availability of irrigation water in the dry periods and deep inundation level in the monsoon may be the main cause of such cropping pattern. Recently a problem is found that is the gradual decreasing of crop production in these areas. Both soil fertility and water table deterioration is noticed as the main causes of this alarming news for North Bengal. As this area is consider as the rice production zone of Northern region of Bangladesh. Over pumping of water during dry season is also a cause to deteriorate the environmental balanced of this wetland. For the betterment of grater environment of this area it is essential to take necessary step to stop all kind of human aggression on wetland. Public awareness should increase about the matter.
\end{abstract}

Key words: Aggression, Chalanbeel, Wetland, Environment.

\section{INTRODUCTION}

Bangladesh is a riverine country. The pride of Bangladesh is for her water ways as they supply a plenty of resources. Specially the wetland of Bangladesh play the crucial role in the development

\footnotetext{
${ }^{1} \mathrm{PhD}$ fellow, Institute of Environmental Science, University of Rajshahi.

${ }^{2} 1$ Institute of Environmental Science, University of Rajshahi, Rajshahi-6205, Bangladesh

${ }^{3}$ Executive Director. Bangladesh Science Foundation, Dhaka, Bangladesh.
} 
of socio economic condition of rural people. Besides its hundreds of river, a vast plenty area of it is covered by wetland. The north eastern part consist numerous wetland which are locally known as beel, jheel, haor, baor. Similarly in the north western parts of the country have a large wetland known as Chalanbeel. It is the largest beel of Bangladesh. It has a lot of significance in various aspects for the livelihood of the people of North western region.

Wetland refers to the notation of an excess of water on the land during part or all of the year and it includes a wide range of inland, coastal and marine habitats which share a number of common features (Moorman, 1990). Wetland soils can thus be defined as "soils whose development and properties are strongly influenced by topography or permanent saturation in the upper part of the land” (Brammer, 1996). Wetlands are acquiring increasing importance in land development and environmental protection. They contain very rich components of bio-diversity like flora and fauna of important local, national and regional significance. Wetlands are essential breading, rearing and feeding grounds for many species of fish and wildlife. They are also important for producing food for humans and domestic animals.

More than two-thirds of Bangladesh may be classified as wetland according to the definition enunciated in the RAMSAR Convention (Saheed, 1984). The wetland environment of Bangladesh is rich in species diversity. They provide a huge habitat of vegetations, aquatic plants, reeds and algae. The floral composition is relatively uniform throughout the haors, baors, beels and jheels. But now the wetlands are shrinking and environmentally degrading day by day due to increased human activities associated with heavy population pressure. It is thus obvious that the wetland of study area is in a great threat specially for human aggression. The study area lies in the lower part of Atrai basin. Atrai basin is a vast depressed area lying between the Tista- Jamuna floodplain. The relief comprises high river levees surrounding extensive basins, the centers of which stay wet throughout the dry season. In the rainy season, basin depressions (core beel centres) become an enormous lake of more than 12 feet deep (SRDI Staff, 1995). Deep and flash flooding, sudden rise of flood level and water current prevent the cultivation of kharif crops in most of the areas. So, the single crop of Boro cultivation/deep water Aman is extensively grown; minor areas are used for seed-beds or grazed fallow. To explore the agricultural potentiality of these wetlands, and to find out the causes responsible for loss of the natural environmental environment of this wetland, a more intensive and detailed study of the area is of prime importance.

The present study aims to depict the vulnerable condition of the natural environment of Chalan bell due to human aggression as well as evaluating the environmental scenarios and agricultural potentials of the area with particular emphasis on the soil fertility status and suggesting probable management options.

The main objectives of this study are to

(i) find out the causes responsible for loss of environment of wetland, Chalan beel

(ii) Assess the importance of Chalan beel in economical and environmental context

(iii) Indicates the threats of wetland occurred due to human aggression

(iv) Provide proper recommendations to protect the natural environment of Chalan beel.

\section{JUSTIFICATION OF THE RESEARCH}

The above said study area is the only mentionable wetland of north eastern region of Bangladesh. About 7 million people are beneficiary directly or indirectly of this wetland. Besides this a plenty of plants and animals (including aquatic) carries their lives based on the Chalan beel. In spite of its unlimited usefulness, it is now under threat. Tremendous human aggression makes this wetland near to loss its characteristics. Where as if it continue to do so then it is not so far that this wetland will totally loss it's balanced. It will carry a curse to the surroundings inhabitants as well as natural environment. Ultimately the result will be very sordid for economical and environmental aspect. It will impose a bad impact on its soil condition. Where as soils in 
Bangladesh occupies an important position so far as their characteristics and management are concerned because $95 \%$ of the total rice area of Bangladesh is on wetland soils (Huq and Kamal, 1993). The rice production of northern region will decrease and thus it may loss its long tradition fame in rich of rice production. Along with lot of threat still there is very little concern noticed about this sensitive issue. No adequate researches are found in this regards. So it is essential to do research about the above title and here lies the keen justification of the research.

\section{LOCATION OF STUDY AREA}

Chalan Beel is an extensive lowland area in the old Brahmaputra and lower Atrai basin. It is located between 24.35 to $24.70^{\circ}$ north latitude and 89.10 to $89.35^{\circ}$ east longitudes. It covers an area belonging to Singra, Grudashpur and Boraigram upazila of Natore district, Chatmohar upazila of Pabna district, Tarash, Roygonj and Ullapara upazila of Sirajganj district and Ahasanganj and Manda Upazila of Noagaon district. It consists of a series of beels connected to one another by various channels to form a continuous water body during the rainy season. Although the beel area expands into a vast water body with dense aquatic vegetation as long as the Jamuna remains flooded during the monsoon months, it dries out in the winter months, leaving only patches of water in the central parts of this zone. The southeastern extremity of the beel is at Astamanisha in Pabna district, close to Nunnagar, where the Gumani and the Baral meet. Its northern boundary in this district may be marked by a line drawn from the east of Singra to the Bhadai river, which forms the boundary between Rajshahi, Pabna and Bogra. The eastern boundary may be represented by a line drawn north-south in Pabna and running through Tarash upazila east of the Bhadai. The greatest breadth of the beel is about $13 \mathrm{~km}$ from Tarash at the northeast to Narayanpur, near the north bank of the Gumani. Its greatest length is about $24 \mathrm{~km}$ from Singra to Kachikata on the Gumani.

\section{MATERIALS AND METHODS}

The materials of the surface area are of recent to sub-recent age. According to an estimate of Brammer (1968), the age of these soils may be around 200 years. The lithology of the recent and sub recent alluvia dominated by silt and clay sized particles (Brammer, 1971). The main rivers in the study area are the Atrai, the Tista and the Jumuna and the courses of these rivers appear to be nearly stable. About $90 \%$ of the area is affected by seasonal flooding. Depth and duration of the flooding vary with topographical position and are mainly controlled by the rainy season water levels of the main rivers and their tributaries.

Four extensive use of wetland by the men is hampered the natural condition of the study area. Specially the over pumping of water for irrigation in winter season for Robi cultivation makes the area imbalanced in many respects. Due to over pumping of ground water the water table in the study area reached down. Study found the water table of this belt reached about 3 meters down during March to May. The aquifer loss its required water due to over pumping by shallow and deep tube well. It is found by pilot survey report on the concern area that 13 thousand shallow and 23 hundred deep tube well settled here for irrigation purpose.(Local interview-20111) Cultivation reached at apex position here and it touches near about the core of the beel. Very few vacuum areas are found but agriculture. The core part of the beel where water logged highly around the year is not possible for agriculture but local people used this type of marshy land for fishing. Some giant land lord as well as influential person using this area like shrimp culture of coastal area. They also demarked some certain area as Ghare for fish culture. The tremendous human aggression leads this wetland to loss its characteristics. Various types of impact found in different sides on this wetland due to human aggression. The soil of this wetland affects more. Both biotic and abiotic members of this study area affected. Direct effect fall on aquatic plants and animals. Fish production of this wetland decreasing day by day at an alarming rate due to lack of fish breeding environment. To assess the soil changing characteristics some test has been 
done as a symbolic proportion. Sample collection has been done from various Upazilas of the study area. A representative soil series have been studied to evaluate the agricultural potentialities of the area. The soil series identified and studied were Singra, Boraigram of Natore, Atghoria of Pabna and tarash of Sirajganj district. GPS have been used to locate the geographical position of the soil samples. Singra series is located at $24^{0} 21^{\prime} 49^{\prime /} \mathrm{N}$ to $24^{0} 42^{\prime} 22^{\prime} \mathrm{N}$ and $88^{0} 02^{\prime}$ E to $8^{0} 88^{0}$ $24^{\prime} \mathrm{E}$ in the medium highland phase. It is seasonally shallowly flooded, poorly drained soils developed in mixed textured alluvium occupying in the gently sloping ridges. They have mixed grey and dark brown, friable, silt loam to loam subsoil with strong to moderate sub-angular blocky structure and patchy to continuous grey cutans on ped faces. Boraigram series is located at $24^{0} 10^{\prime} \mathrm{N}$ to $24^{0} 22^{\prime} \mathrm{N}$ and $88^{0} 01^{\prime} \mathrm{E}$ to $88^{0} 18^{\prime} \mathrm{E}$ in the slope of basin. It is poorly drained, seasonally deeply flooded soils developed in the basins and basin margins of old Brahmaputra floodplain. They have a grey to dark grey, clay sub soil usually with strong prismatic and angular blocky structure and continuous grey or dark grey cutans along the ped faces. Atgharia series is located at $24^{0} 07^{\prime}$ to $24^{0} 66^{\prime} \mathrm{N}$ and $88^{0} 15^{\prime} \mathrm{E}$ to $88^{\circ} 26^{\prime} \mathrm{E}$ in the nearly level basin sites. It comprises seasonally very deeply flooded, very poorly drained, moderately fine textured soils developed in the Tista valley of the Atrai basin. They have a dark grey to very dark grey, mottled brown, silty clay loam sub soil. Tarash series is located at $24^{0} 20^{\prime} \mathrm{N}$ to $24^{0} 34^{0} \mathrm{~N}$ and $88^{0} 08^{\prime} \mathrm{E}$ to $88^{0} 33^{\prime}$ E (Banglapedia- 2003) in the basin depressions. It comprises seasonally very deeply flooded, very poorly drained soils developed in fine textured alluvium on the Buri Tista valley of the Atrai basins. They have a very dark grey, silty clay to clay. A horizon with common brown mottles overlying a silt loam to silty clay loam oxidized substratum.

Soil samples were collected and air dried, grinded and screened through sieve. The samples were analyzed for $\mathrm{pH}$, organic matter, N, P, K, Ca, Mg, S, B, Cu, Zn, Fe and Mn. The extraction procedure and interpretation of soil samples were made as Agro-Services International methodology and $\mathrm{pH}\left(\mathrm{H}_{2} \mathrm{O}\right)$ of soils was determined at a soil-water ratio 1:2.5 using a pye $\mathrm{pH}$ meter. The organic carbon content of soils was determined volumetrically by wet oxidation method as described by Jackson (1996). The total nitrogen in soils was determined by Kjeldahl's method as described by Jackson (1996). Available phosphorous was determined by Olsen method (Jackson, 1962). Ammonium acetate extract was prepared and the exchangeable Ca, Mg, K were determined from the extracts (Black, 1965). Soil physical attributes were assessed in the field using standard field methodology (FAO, 1977).

\section{RESULTS AND DISCUSSION}

The studied wetland environment is highly affected by verities of human aggression like construction of road and embankments, culvert, industries, settlement etc. Besides these there is some natural calamity like drought, severe flood, seasonal imbalance out broken, adverse weather and climatic condition impose a bad effect on the wetland. Some other reason act as the disturbance of this natural landscape like difficulty of controlling the enormous quantities of water entering from outside the region which ultimately limits, to a greater extent, the agricultural potentialities of the area. Improper distribution of rainfall and its distribution pattern of the investigated area are also a vital reason to change the natural condition of the wetland. Study found that the total area of the wetland is shrinking due to above reasons year after year. A survey carried out by the Public Works Department into drainage and silting up of the beel found that the previous area of about 1,088 sq km have been reduced to about $368 \mathrm{sq} \mathrm{km}$. The remaining area had been reclaimed either for cultivation or settlement. Even in this reduced area, only 86 sq $\mathrm{km}$ was found under water all the year round. It was estimated that the feeder rivers had brought 6.3 million cu $\mathrm{m}$ of silt a year of which 1.5 million cu $\mathrm{m}$ were washed away by different drainage channels coming out of the beel. The remaining 4.8 million cu $\mathrm{m}$ had been deposited annually. If distributed uniformly over the whole of $368 \mathrm{sq} \mathrm{km}$, it would have raised the level at the rate of $1.27 \mathrm{~cm}$ a year. Another inquiry was made in 1910 to further ascertain the condition of the beel during the dry season. It too found that the area had been further reduced. A third investigation carried out in 1913, ascertained that only 31 to $39 \mathrm{sq} \mathrm{km}$ remained under water throughout the 
year. The banks around the core area were under cultivation and the beel proper had 2.75 to $5.49 \mathrm{~m}$ of water in April. In the 1950s, various reclamation works reduced the beel to about 25.9 sq km. In 1987, it appeared completely dry except for some small man-made ponds. (Alam \& Hossain-2003)

Chalan beel is rapidly silting up. During the last century and a half, it has shrunk at least 19.32 $\mathrm{km}$ from the southern side due to annual deposits of silt from the Ganges. Its other feeder rivers like the Gurai and the Baral are also major contributory factors in reducing the size of the beel.

Some physical attributes of the studied area is shown in Table-1. The field textural class was silt loam in the Singra, Boraigram and Atghoria soil series whereas Tarash series was silty clay. The best soils for agricultural crops are the silt loam and clay loam (ICLARM, 1988) which showed relevancy with the above textural class. Soil texture always influences the drainage conditions of the soils as well as crop performance. The drainage conditions of these soils varied from poor to very poor.

Chemical features of the soils under investigation have been presented in Table-2. The organic matter content of the soils varied from 0.96 to 1.17 with a mean of 1.10 percent. The $\mathrm{pH}$ value of the studied wetland soils ranged from 6.7 to 7.0 with a mean of 6.9. The decomposition and mineralization of organic matter are interrelated with successive changes in chemical reduction of the soils resulting in the lowering of redox potential and changes of $\mathrm{pH}$ to near neutrality (IUCN, 1993).

Total nitrogen contents in the studied soils ranged from 0.07 to 0.09 percent (Table-2). The low nitrogen content of the soils may be attributed to the loss through denitrification. The denitrification was probably due to the poor drainage condition of the soils. The $\mathrm{C} / \mathrm{N}$ ratio of the studied soils ranged from 6 to 9 indicating agricultural suitability of these soils.

Potassium contents of the soils ranged from 0.31 to $0.85 \mathrm{Cmol}\left(\mathrm{p}^{+}\right) \mathrm{Kg}^{-1}$ with an average of 0.48 $\mathrm{Cmol}\left(\mathrm{p}^{+}\right) \mathrm{Kg}^{-1}$. Sodium contents of the soils ranges from 1.00 to $1.13 \mathrm{Cmol}\left(\mathrm{p}^{+}\right) \mathrm{Kg}^{-1}$ with an average of $1.04 \mathrm{Cmol}\left(\mathrm{p}^{+}\right) \mathrm{Kg}^{-1}$ (Table- 2). Calcium contents varied from ranged from 7.20 to

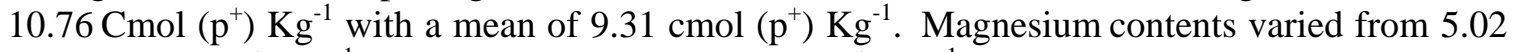
to $7.40 \mathrm{Cmol}\left(\mathrm{p}^{+}\right) \mathrm{Kg}^{-1}$ with an average of $6.33 \mathrm{cmol}\left(\mathrm{p}^{+}\right) \mathrm{Kg}^{-1}$ and can be considered as high. The $\mathrm{Ca} / \mathrm{Mg}$ ratio of the studied soils varied from 1.30 to 1.80 and the mean ratio was 1.50 (Table 2). Hence, the level of basic cations is not satisfactory as because of the non-calcareous nature of the parent materials of this area. The $\mathrm{Mg} / \mathrm{k}$ ratio varied from 8.67 to 20.23 the average being 13.25. Available P contents varied from 7.0 to 23.0 micro-gm/ml with an average of 16.25 micro-gm $/ \mathrm{ml}$ (Table 2). Here, low category of $\mathrm{P}$ may be due to the intensive cropping of the basin area. Slow release fertilizer can be used during land preparation or incorporated with soils prior to the transplanting of rice.

Sulphur contents varied from 23.0 to $49.0 \mathrm{micro}-\mathrm{gm} / \mathrm{ml}$ soil with an average of 33.75 micro$\mathrm{gm} / \mathrm{ml}$. Removal or burning of the rice straw in combination with the use of sulphur free fertilizers has resulted in depletion of sulphur. It can be remedied by the supply of sulphur containing fertilizers like ammonium sulfate or gypsum. Boron contents varied from 0.06 to 0.14 micro-gm/gm and average 0.11 micro-gm/ml. Zinc contents varied from 2.7 to 6.5 micro-gm $/ \mathrm{ml}$. Zinc deficiency was generally observed in soils with rice cultivated areas of Bangladesh (Saheed, 1984). Copper contents varied from 8.6 to $19.9 \mathrm{micro}-\mathrm{gm} / \mathrm{ml}$ and average $14.57 \mathrm{micro}-\mathrm{gm} / \mathrm{ml}$. Iron content varied from 324.0 to $523.0 \mathrm{micro}-\mathrm{gm} / \mathrm{ml}$. Manganese contents varied from 46.7 to $105.1 \mathrm{micro}-\mathrm{gm} / \mathrm{ml}$ and average was $76.52 \mathrm{micro}-\mathrm{gm} / \mathrm{ml}$ (Table 2). The reaction of the soil enhanced the availability of $\mathrm{P}$, Mo and while depressing the toxicity of $\mathrm{Mn}, \mathrm{Al}$ and Fe. Here antagonistic effect of manganese and possibly of magnesium on zinc uptake by rice plants is expected (Sakai, 1979).

To assess the agricultural potentiality of the studied soils, the nutrients were classified into three categories as low, medium and optimum using the recommendation of BARC (2005). From that recommendation, the studied soils were matched and categorized according to their potentialities. In the present investigation, the soils were highly productive nutritionally. The content of nitrogen and boron is low. The application of boron should be advised as trace amount; the 
application of nitrogen should also be advised according to its yield goal level. Probably, the denitrification process leads to the loss of nitrogen in this basin soils, otherwise the other nutrients maintains a balance dose for the successful growth of rice. Comparing the past and present land use data, HYV Boro and deep water T. Aman were introduced in the study area. Irrigation facility in the dry season and shallow inundation level in the monsoon may be the main cause of such cropping pattern. There is a considerable change in land use along with their changes in soil properties.

Agricultural viability of soils depends on the organic carbon content. Organic carbon is the skeleton of the soil mass and acts as a regulator of soil bio-chemical and physico-chemical behavior. On the other hand, soil $\mathrm{pH}$ plays a very vital role in grouping the soils into different classes and has a profound influence on many factors connected with the suitability of a soil for agricultural use. Considering the above points, organic carbon and $\mathrm{pH}$ value of the four soil series were compared with the semi-detailed soil survey data of SRDI Staff (1995). From the database, it is found that soil pH stands near neutral from slightly acidic conditions since 1990's. In case of organic carbon, it has been noticed that there is no changes in organic carbon content as a whole in the studied soils. In this connection, it can be strongly advised that the studied soils will be remained productive in respect of their agricultural use.

\section{CONCLUSIONS}

Chalan beel is the largest and important wetland in the north western region of Bangladesh playing vital role to keep tremendous contribution in various arena. Both life and nature is beneficiary of this large water reservoir. It acts as the benediction for people and other beings of whole north western region. But curse carrying by men on this wetland. The crucial ruling of man on chalan beel makes it imbalanced situation. The aggression of men compelled this wetland to change its natural behavior. Fertility level of this area is moderate to optimum and is believed to be enriched by siltation during flooding. But the fact of alarming is that its fertility rate is decreasing day by day. Annual siltation is a characteristic feature of this wetland now a day where from the traditional natural fertility of these soils is derived. The land use depends on the timing and duration of flooding. With the introduction of irrigation along with HYV (High Yield Variety) of rice, the cropping pattern has been changed and HYV Boro rice got preference over broadcast Aman and Aus as a major rice crop in the area. Due to the changes in cropping pattern, demands for nitrogen and phosphorus fertilizer have increased. There is no considerable change in organic carbon content and the $\mathrm{pH}$ value stands near neutral which indicates the agricultural viability of the studied soils. The present investigations ascertained that the study area including the wetlands can be economically utilized through appropriate nutrient management and selecting the proper cropping patterns. Another vulnerable news arise is the study area due to over aggression of human settlement. This leads the decreasing volume of this beel. Land in Chalan beel is being reclaimed and new villages are springing up alongside. In the dry season, all the smaller and larger beels dry up except their deeper centre. The outlying marginal lands are cultivated with boro and HYV rice in the dry season. In the wet season, the shallow peripheries are cultivated for deep-water Aman rice and jute.

This study provides an overview of the current resources and fisheries status of the Chalan beel, which reveals not a good message for man and environment. The study also identifies the scope of opportunities to evolve existing fisheries management strategies, focusing on fish biodiversity conservation. This largest, most important watershed in the North Central Bangladesh, and covers an area of about $375 \mathrm{~km}^{2}$ during the monsoon season is now in threat. The watershed serves about 5 million people, predominantly through fisheries and agricultural activities. Although considerably degraded over time, Chalan beel still supports a diverse ichthyofauna of major importance to the local economy and people's livelihoods. The Chalan beel area incorporates 21 rivers and 93 smaller seasonal beels of varying size. Most of the rivers and beels are at risk of 
partial or total degradation, as a result of agricultural encroachment, siltation and other anthropogenic activities. During the study, $83 \%$ of the rivers, and $68 \%$ of the beels in the lean season, shrunk to $0-5 \%$ of their maximum (monsoon) water-spread area during the dry season (i.e. critical levels for survival of many fish species). A fish catch survey was carried out in the main fishing season (July to December) over two successive years in the three most important catchments areas; namely, the Gumani, Baral and Katagang Rivers. The study results indicate at least 19 fish species once considered abundant can now be classified as threatened, with a possibility of local extinction. In 2005-2006, the annual fish production in Chalan beel was 12 217 tons, being less than half of the production observed in 1982. The stakeholders identified several major causes they thought were directly responsible for the continued decrease in fish production and biodiversity of the beel area. Several management strategies were suggested by the same stakeholders, and the findings are discussed in the context of overall developments in the Chalan beel fisheries related to habitat and biodiversity management. Study focused mainly on causes responsible for the loss of natural environment of the wetland and found human aggression as the prime factor responsible for it.

Table 1. Physical attributes of the studied soils.

\begin{tabular}{|c|c|c|c|c|}
\hline Soil series & Topography & Drainage & Texture & Land type \\
\hline Singra & Submerged & Poor & Silty clay & Very Low land \\
\hline Boraigram & Gently relief & Smooth & Silt loam & Lowland \\
\hline Atghoria & Gently sloping & Medium & Clay loam & Low land \\
\hline Tarash & Basin depression & Very poor & Silty clay & Very Lowland \\
\hline
\end{tabular}

Source: BBS, 2005

Table 2: Nature and properties of the soils under study in the wetland basin area.

\begin{tabular}{|c|c|c|c|c|c|c|c|c|c|c|c|c|c|c|c|c|}
\hline \multirow{2}{*}{$\begin{array}{l}\text { Soil } \\
\text { series }\end{array}$} & \multirow{2}{*}{$\begin{array}{l}\mathrm{OM} \\
\%\end{array}$} & \multirow{2}{*}{$\begin{array}{l}\text { Tota } \\
\text { l } \\
\mathrm{N}\end{array}$} & \multirow{2}{*}{$\begin{array}{l}\mathrm{C} / \mathrm{N} \\
\text { ratio }\end{array}$} & \multirow[t]{2}{*}{$\mathrm{pH}$} & \multicolumn{5}{|c|}{$\mathrm{Cmol}\left(\mathrm{p}^{+}\right) \mathrm{Kg}^{-1}$} & \multicolumn{7}{|c|}{ micro-gm/ml } \\
\hline & & & & & $\mathrm{Na}$ & $\mathrm{K}$ & $\mathrm{Ca}$ & $\mathrm{Mg}$ & $\begin{array}{l}{ }^{1} \mathrm{NH} 4- \\
\mathrm{N}\end{array}$ & $\mathrm{P}$ & $\mathrm{S}$ & ${ }^{1} \mathrm{~B}$ & ${ }^{1} \mathrm{Zn}$ & ${ }^{1} \mathrm{Cu}$ & ${ }^{1} \mathrm{Fe}$ & ${ }^{1} \mathrm{Mn}$ \\
\hline Singra & 1.10 & 0.09 & 6 & 6.7 & 1.01 & 0.50 & 7.2 & 5.02 & 17.0 & 7.0 & 23.0 & 0.11 & 2.7 & 8.6 & 324.0 & 46.7 \\
\hline Boraigram & 0.96 & 0.07 & 8 & 6.9 & 1.00 & 0.55 & 9.7 & 6.70 & 23.0 & 23.0 & 27.0 & 0.14 & 3.1 & 13.1 & 418.0 & 70.6 \\
\hline Atghoria & 1.13 & 0.09 & 7 & 6.9 & 1.02 & 0.31 & 10.7 & 6.20 & 43.0 & 13.0 & 49.0 & 0.13 & 4.5 & 19.9 & 365.0 & 83.7 \\
\hline Tarash & 1.17 & 0.08 & 9 & 7.0 & 1.13 & 0.85 & 9.5 & 7.40 & 25.0 & 22.0 & 36.0 & 0.06 & 6.5 & 16.7 & 523.0 & 105.1 \\
\hline Mean & 1.10 & 0.08 & 8 & 6.9 & 1.04 & 0.48 & 9.3 & 6.33 & 26.2 & 16.2 & 33.7 & 0.11 & 4.2 & $\begin{array}{l}14.5 \\
7\end{array}$ & 407.0 & 76.5 \\
\hline
\end{tabular}

OM =Organic matter; $\mathbf{C} / \mathbf{N}=$ Carbon $/$ Nitrogen $\quad{ }^{1}$ Data source: SRDI Staff, 1995.

\section{REFERENCES}

Hossain M. A. 2005 Fisheries resource development of Chalan beel. Key note speech of a

National Seminar. Organized by North West Fisheries Resource Development and Management Project (Third Phase), Parbatipur, Dinajpur, Department of

Fisheries, Bangladesh.

BBS, 2005, Compendium of Environmental Statistics of Bangladesh, Bangladesh Bureau

of Statistics, Ministry of Planning, Govt. of Bangladesh, Dhaka P153

Alam, M, Samsul Hossain M, Sazzad.2003, Article on Chalan beel, Banglapedia, the national Encyclopedia,Vol-1, Dhaka

FAO. 1977. Guidelines for Soil Profile Description. Soil Resources Development and Conservation Services. FAO of the UN, Rome. 
Huq, S. M. I. and G. M. Kamal. 1993. Characteristics and dynamics of wetland soils. Freshwater Wetlands in Bangladesh: Issues and Approaches for Management. IUCN Bangladesh Country Office, Dhaka, Bangladesh.

IUCN. 1993. Characteristics and Dynamics of wetland soils in Bangladesh. IUCN. Wetland Publication, Dhaka, Bangladesh.

Karim, Z.; A. Iqbal. 2001. Impact of Land Degradation in Bangladesh, Changing Scenario in Agricultural Land Use.

Soils Publication No. 42. Bangladesh Agricultural Research Council , Bangladesh.

Moorman F. R. 1953. Acid Sulphate Soils of the Tropics. Soil Sci. 95: 271-275.

SRDI Staff. 1995. Land and Soil Resource Utilization Guides of Singra Thana of Natore district (revised edition). GoB, Soil Resource Development Institute. Bangladesh

Saheed, S. M. 1984. Soils of Bangladesh. Pp. 107-129. Proc. Int. Symp. Soil Test Crop Response Correlation Studies. BARC and SSSB, Dhaka, Bangladesh.

Sakai, H. 1979. Reports of Research Activities 1977-79. IRRI Agronomist, BRRI Joydevpur, Bangladesh. P. 23. 


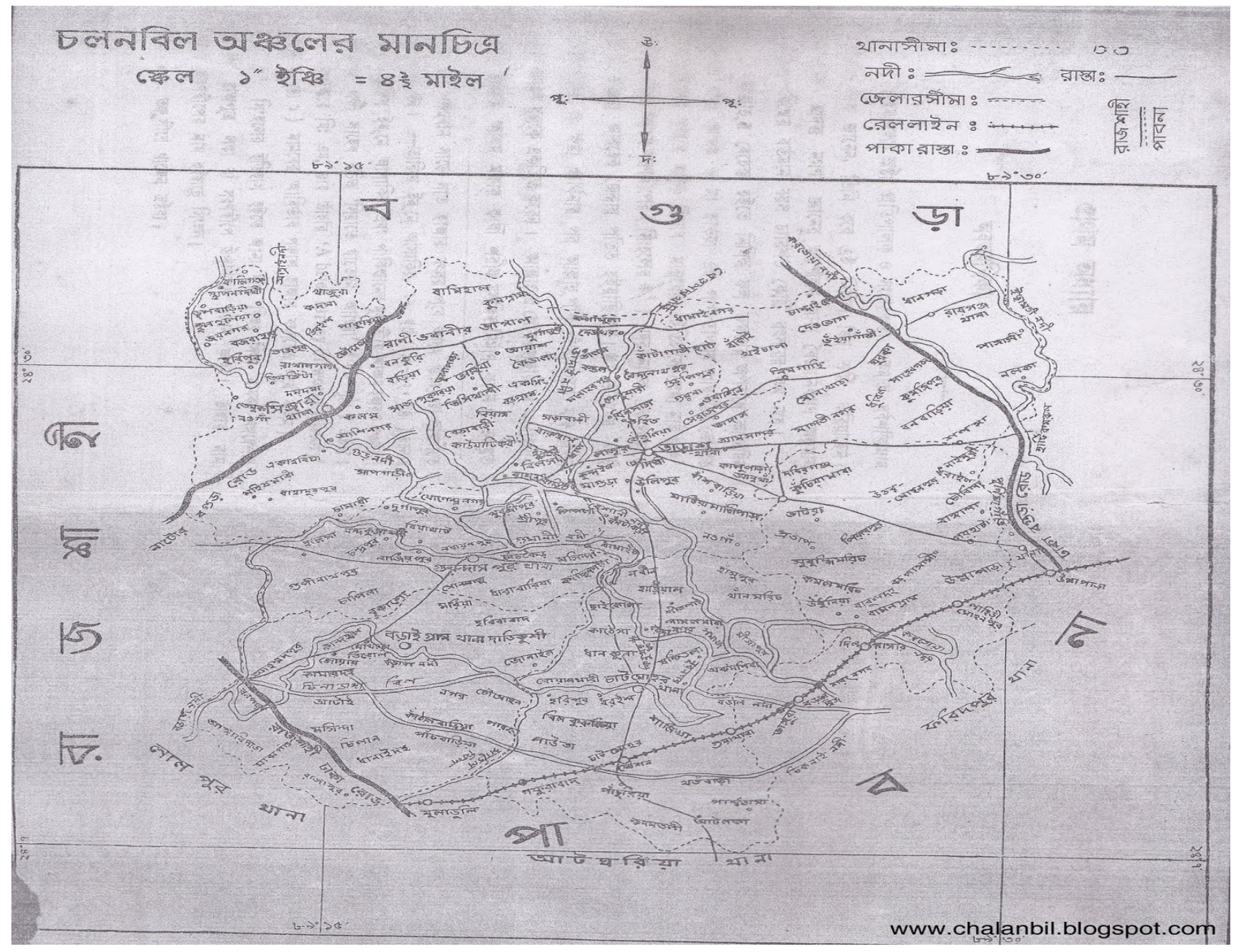

Fig.1:Location map of the study area(Chalanbeel)


Pic-1: Wetland area related with chalanbee

Pic-2: vast water of chalenbeel during rainy season 